\title{
Sectoral Features of the Tenir-Too Mountains
}

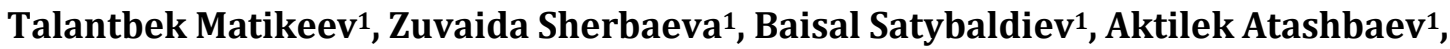 \\ Umida Isakova ${ }^{1}$, Zhypargul Abdullaeva ${ }^{2 *}$
}

${ }^{1}$ Department of Physical Geography and Applied Geodesy, Osh State University, Osh, Kyrgyzstan

${ }^{2}$ Department of Science and Research, Osh State University, Osh, Kyrgyzstan

Email: *jypar.science@oshsu.kg

How to cite this paper: Matikeev, T., Sherbaeva, Z., Satybaldiev, B., Atashbaev, A., Isakova, U., \& Abdullaeva, Z. (2021). Sectoral Features of the Tenir-Too Mountains. Journal of Geoscience and Environment Protection, 9, 68-74.

https://doi.org/10.4236/gep.2021.91005

Received: December 9, 2020

Accepted: January 19, 2021

Published: January 22, 2021

Copyright $\odot 2021$ by author(s) and Scientific Research Publishing Inc. This work is licensed under the Creative Commons Attribution International License (CC BY 4.0).

http://creativecommons.org/licenses/by/4.0/

\begin{abstract}
For the first time, the separating issues of the Tenir-Too mountains into sectors in contrast to the accepted schemes of physical geography as a province and sub-province were discussed. Since the term province is more acceptable in political science than in physical geography, the main factors in the process of sector formation were determined. The purpose of this article is not only to describe the high altitudes of the Tenir-Too mountains, but theoretically substantiate their formation, ecological and genetic features, and distribution patterns. Until today the Tenir-Too mountain area is not divided into sectors and subsectors with significant changes to the stencil scheme, which has been used to date in the physical geographical zoning. Research methods in this work are based on the recent study materials collected from meteorological stations of Tenir-Too region. Hypsometric and topographic maps were used to identify high altitude ranges, and climatic factors were separated by zones. Plant species and genus divisions were identified. In some areas of the Tenir-Too the range of altitudes along the routes was studied.
\end{abstract}

\section{Keywords}

“Zone Set", Sector, Subsector, Exposure, Side Mountains,

Climatic Adaptation, Homogeneous Area, Adjacent Area,

Double Zonation, Arid, Humid

\section{Introduction}

According to the definition in the "Encyclopedic Dictionary of Geographical Terms" (Kalesnik, 1968), the term sector is defined as a large part of the continents, differing in structures of zoning ("set" of zones), which is associated with varying degrees of atmospheric moisture, seasonal rhythm, and the degree of continentality. The boundary of their summit is sharp only in the presence of 
meridional orographic boundaries. Sectoral allocation is one of the basic laws in physical geography as natural zones in the world, their physical and geographical nature changes in latitudinal and meridional directions.

The reasons for this are not the same location and structure of the relief of the earth's surface, the composition of rocks, vegetation and soil cover, and climatic conditions of the regions. Sectorality is a part of a natural zone, characterized by an uneven distribution of solar energy, as a result of which the vegetation and landscape envelope gets a peculiar look. Uneven precipitation and annual solar energy are the main factors. Sectorality is a general planetary law that applies to the ocean and land. Based on the moist air mass coming from the west, the continental sector is divided into symmetric and asymmetric.

The significance of this work is determining the influence of geographical locations including tectonic, climatic and geological factors on the sectors formation of the Tenir-Too mountains, and analysis of peculiarities in formation of high altitudes. The physical and geographical features of sectors formation on Tenir-Too region not analyzed previously, in a new scientific direction, as they are carried out in a fragmentary state, and a unified theoretical, methodological and economic-forecasting system has not been developed.

Due to the fact that the open geomorphological valleys are located in a tectonic fault that occupies a large area, the relief in terms of elevation profile consists of several geomorphological complexes such as low, medium and high mountains. Orientation of the relief corresponds to the orientation of the ancient rivers and the same age as the rocks of the terraces and has changed under the influence of geological factors in later periods. In this regard, it is important to determine the formation of sectors in different areas of Tenir-Too.

\section{Atmospheric Precipitation by Areas}

The atmospheric precipitation is influenced by factors affecting the spatial and temporal distribution around mountains, as precipitation in mountainous environments is higher in some regions and lower in others, as well as important characteristic of precipitation in mountainous areas is its relation to the elevation (Shrestha et al., 2015).

The Tenir-Too mountain systems as a whole are affected by humid air masses coming from the west during the year, cold air masses from the Northern Ocean in winter, hot air masses of the Central Asian desert in summer, and the Mongolian anticyclone in winter, i.e. Tenir-Too mountains are influenced by 4 different air currents coming from different directions. The territory of Tenir-Too receives atmospheric precipitation from the humid western air mass. But due to the different directions of the side ridges, atmospheric precipitation is unevenly distributed over large valleys (Talas, Chatkal, Chui, Issyk-Kul, Kemin, Ak-Sai, Arpa, Chatyr-Kul, Middle Naryn, Ketmen-Tobo, Suusamyr, etc.). A similar picture is typical for climatic indicators. On the example of the Talas valley, the annual amount of atmospheric precipitation ranges from $300 \mathrm{~mm}$ (flat part) to $600 \mathrm{~mm}$ 
(mountainous part) the average temperature in January is from $-6^{\circ}$ to $10^{\circ}$, in July is from $+16^{\circ}$ to $+26^{\circ}$; in the Chatkal valley, the annual precipitation ranges from $500 \mathrm{~mm}$ (in the flat part) to $1000 \mathrm{~mm}$ (in the mountainous part), the average temperature in January is from $-3^{\circ} ;-5^{\circ}$ to $10^{\circ} ;-15^{\circ}$, in July from $+22^{\circ}$; $+25^{\circ}$ to $0^{\circ} ;-5^{\circ}$; in the Chuy valley, the annual precipitation ranges from $500 \mathrm{~mm}$ (in the flat part) to $700 \mathrm{~mm}$ (in the mountainous part), the average monthly temperature in January is from $-4^{\circ}$ to $-31^{\circ}$, in July from $+20^{\circ} ;+25^{\circ}$ to $0^{\circ} ; 2^{\circ}$; in the Issyk-Kul valley annual precipitation ranges from $140-200 \mathrm{~mm}$ (western part) to $800 \mathrm{~mm}$, average monthly temperature in January is from $-4^{\circ} ; 6^{\circ}$ (western part), July from $+15^{\circ} ;+20^{\circ}$ (eastern part), and in the mountains $0^{\circ} ; 3^{\circ}$; in the Kemin valley, the annual precipitation ranges from $300-350 \mathrm{~mm}$ to $700-800$ $\mathrm{mm}$, the average January temperature is from $-5^{\circ} ; 6^{\circ}$ to $-10^{\circ} ; 15^{\circ}$, the average July temperature is from $+17^{\circ} ;+18^{\circ}$ (flat part) to $0^{\circ} ; 3^{\circ}$ (mountainous part); in the Aksai valley, the annual precipitation ranges from $200 \mathrm{~mm}$ (in the eastern part) to $400 \mathrm{~mm}$ (in the western part), the average January temperature is from $-15^{\circ}$ to $-26^{\circ}$, in July from $0^{\circ}$ to $+5^{\circ}$; in the Arpa valley the annual amount of atmospheric precipitation is $250-280 \mathrm{~mm}$, the average temperature in January is from $-23^{\circ}$, in July from $+9^{\circ}$; in the Chatyr-Kul valley, the annual amount of atmospheric precipitation is $208-209 \mathrm{~mm}$, the average January temperature is from $-5.6^{\circ}$, July $+24^{\circ}$; in the Middle Naryn Valley, the annual precipitation is $350-500 \mathrm{~mm}$, the average January temperature is from $-13.7^{\circ}$ to $-17^{\circ}$, in July from $+9.2^{\circ}$ to $+17.1^{\circ}$; in the Suusamyr valley the annual precipitation is $350-$ $370 \mathrm{~mm}$, the average January temperature is from $-30^{\circ} ; 31^{\circ}$, in July from $+13^{\circ}$; $+14^{\circ}$; in the Kemen-Tubinskaya depression, the annual precipitation is $367 \mathrm{~mm}$, the average temperature in January is $-14^{\circ}$, in July $+24^{\circ}$; In the Toguz-Toro basin, the annual precipitation is $320-350 \mathrm{~mm}$, the average temperature in January is $-17^{\circ} ; 19^{\circ}$, in July $+22^{\circ} ;+23^{\circ}$.

Climate shifts around the Pleistocene-Holocene transition are results in the regional temperature variations and humidity in geological, palaeobotanical and archaeological information (Chlachula, 2019). As a result of these indicators, during the Holocene (5.0 thousand years), peculiar altitudinal belts with different heights and ranges, forming continuous belts in some valleys, in separate ruptured isolate-closed belts, the formation of which is associated with humid and arid regimes. Where the humid regime forms continuous belts on the slopes of all exposures (Ak-Sai, Chatyr-Kul, Arpa, Suusamyr), where the arid regime forms isolated-closed belts (Ketmen-Tobo, Toguz-Toro, Chatkal, Talas, in the valley of the Inner Naryn, Chui, Issyk-Kul, etc.). Isolation of which is associated with the contour of the climatic area and adaptation vegetation cover of arid, semi-arid, semi-humid, and humid regimes. As a result, in many mountain valleys and depressions of Tenir-Too, landscape areas are formed in the form of patches fragmentarily from deserts to the glacial-nival landscape.

\section{Climatic-Areal Locality}

Estimating the impacts of climate change is important due to a large number of 
ecosystems services and economic sectors which can vary strongly by regions (Monier et al., 2018). Climatic-areal is a locality characterized by a set of climatic conditions, characterizing any homogeneous area of the earth's surface, where the dynamics of the components differs significantly from certain areas. The difference between the dynamic links of the components is formed by the patchwork mosaic of the landscape and the movement of isolated-closed belts. As a result, a "double belt" is formed, consisting of several sub-belts. The "double belt" of the Tenir-Too mountains is composed of two to four sub-belts, depending on the geographical position and the type of climatic regime: arid, semi-arid, moderately humid, highly humid, and waterlogged. Aridity increase across the entire Central Asian region, in the western parts of Turkmenistan, Uzbekistan, and Kazakhstan resulting in temperature increases high in summer and fall and decreases in precipitation (Lyubimtseva \& Henebry, 2009). The arid type high-altitude belts occur in the form of hot semi-deserts and semi-deserts; cold deserts and semi-deserts. Deserts and semi-deserts of the arid regime are characteristic of the flat part of the Talas and Chuy valleys, located adjacent to the Central Asian deserts and the Kazakh steppes, where semi-arid and arid types of climatic conditions are characteristic. The semi-arid type of climate and altitude zones is a transitional zone between desert and dry steppe landscapes, deserts and semi-deserts of the humid regime are characteristic in a fragmentary form in the Aksai valley (3000 - 3600 m), Arpa (3000 - 3500 m), Sary-Jaze (3700 - 3900 m), Koolu (3600 - 3700 m), in Kakshaal (3400 - 3800 m), where alpine meadows and meadow-steppe landscapes form a continuous belt. The upper isoline of the belt runs along with an altitude of $4200 \mathrm{~m}$, and the lower one at an altitude of $3900 \mathrm{~m}$. These indicators in the Arpa valley are equal to $3000-3500 \mathrm{~m}$, in the Koolu valley 3400 - 3700 m, in Sary-Zhaz 3700 - 3900 m, respectively (Glazovskaya, 1955; Mamytov, 1964; Vyhodtsev, 1967).

Geotectonists and formation of altitudinal belts of the Pamir-Alai mountains begins from the Upper Pliocene (3 - 1 million years ago) when the Tenir mountains Too climbed to 2300 - 2500 m height (Loskutov, 1969; Pahamov, 1971; Chediya, 1971; Popova, 1967; Sherbaeva, 2009). The uplift of the Fergana Ridge caused aridization of the climate, which led to the displacement of desert-steppe, desert, and boreal groups of plants (Agakhanyants, 1981), which were located in different climatic areas. "Patch-like" shape on all mountain ranges, valleys, and depressions of Tenir-Too, i.e. isolated-closed belts are the remnants of belts of the historical period. Modern high-altitude zones are typological vegetation, i.e. by the interpenetration of representatives of one type of vegetation in a community of other types. These patterns are associated with the presence of mixed types of plants (semi-deserts, desert steppes, meadow-steppes, dry-steppe, high-altitude meadows, low-grass meadows, forest-steppe, etc.), which are the basis for identifying the high-altitude belts of the Tenir-Too mountains. This is an adaptive feature associated with the heterogeneity of habitats-the climatic area manifested in the lateral mountains of large mountain systems (Kakshaal, 
Fergana, Talas Ala-Too, Teskey Ala-Too, Kungoy Ala-Too, Kyrgyz Ala-Too, etc.) and high mountain valleys and hollows Tenir-Too.

\section{Sectoral Features in the Tenir-Too Mountains}

In the process of the formation of the Tenir-Too sector feature, one of the main roles belongs to the degree of moisture, which plays an important role in the formation of the external appearance is a mosaic of high-altitude zones of sectors and subsectors. Air humidity is the content of water vapor in the air, characterized by water vapor pressure, absolute humidity, relative humidity, and humidity deficiency, based on which the climate is divided into arid and humid climates. In the sectors of Tenir-Too, due to the sharp ruggedness of the relief, the humidity changes sharply along the valleys, basins, and slopes of the mountains which determine the appearance of the sectors and sub-sectors.

According to the Atlas of the Kyrgyz SSR (1987), the ratio between the amount of precipitation falling into a given area and evaporation is uneven (Table 1); the degree of moisture and evaporation rate (Table 2) in the Tenir-Too territory is uneven.

Based on the above factors, the following sectoral division of the Tenir-Too mountains was proposed: I. Talas-Chatkal (Chatkal and Talas); II. Chui-Kemin (Chui and Kemin); III. Issyk-Kul (Teskey Ala-Too, Kungoi Ala-Too and Kochkor); IV. Ak-Sai-Sary-Zhaz (Ak-Sai, Sary-Zhaz, Ak-Shyirak); V. Inner Tenir-Too (Suusamyr, Zhumgal, Son-Kul, Ketmen-Tobo, Toguz-Toro) as shown in Figure 1. In the scientific work, for the first time, a scheme for the allocation of the Tenir-Too mountains into sectors and sub-sectors is proposed, contrary to the accepted schemes in physical geography as a province and sub-province. Since the term province has a political meaning than in physical geography and is more acceptable when defining the administrative parts of states. For example, Caucasian, Central Asian, Central Asian, Siberian, etc. its application in the classification scheme of physical and geographical science, as a determining factor of a particular region, is inappropriate.

Table 1. Moisture rate per year.

\begin{tabular}{cccccc}
\hline \multicolumn{4}{c}{ Humidification coefficient and evaporation degree } & Low- \\
Sectors & Plain zone & $\begin{array}{c}\text { Adyrno- } \\
\text { perdgornaya } \\
\text { zone }\end{array}$ & $\begin{array}{c}\text { Mountain } \\
\text { zone } \\
\text { Mountain } \\
\text { zone }\end{array}$ & $\begin{array}{c}\text { High- } \\
\text { mountain } \\
\text { zone }\end{array}$ \\
\hline Talas-Chatkal & $0.1-0.2$ & $0.2-0.4$ & $0.4-0.6$ & $0.6-0.8$ & $0.8-1.0$ \\
Chui-Kemin & $0.2-0.4$ & $0.4-0.6$ & $0.6-0.8$ & $0.8-1.0$ & $>1.0$ \\
Issyk-Kul & $0.1-0.2$ & $0.4-0.6$ & $0.6-0.8$ & $0.8-1.0$ & $>1.0$ \\
Ak-Sai-Sary-Zhaz & $0.2-0.4$ & - & $0.4-0.6$ & $>1.0$ & $>1.0$ \\
Inner Tenir-Too & $0.1-0.2$ & $0-0.2$ & $0.4-0.6$ & $0.6-0.8$ & $>1.0$ \\
& $0.1-0.2$ & $0.2-0.4$ & $0.4-0.6$ & $0.6-0.8$ & $>1.0$ \\
& insignificant & meager & insufficient & nonstable & excess \\
\hline
\end{tabular}


Table 2. Evaporation rate ( $\mathrm{mm}$, per year).

\begin{tabular}{cccccc}
\hline Sectors & Plain zone & $\begin{array}{c}\text { Adyrno- } \\
\text { perdgornaya } \\
\text { zone }\end{array}$ & $\begin{array}{c}\text { Low- } \\
\text { mountain } \\
\text { zone }\end{array}$ & $\begin{array}{c}\text { Mid- } \\
\text { Mountain } \\
\text { zone }\end{array}$ & $\begin{array}{c}\text { High- } \\
\text { mountain } \\
\text { zone }\end{array}$ \\
\hline Talas-Chatkal & Up to 600 & $600-800$ & $800-1000$ & $0.6-0.8$ & $0.8-1.0$ \\
Chui-Kemin & $200-400$ & $600-800$ & $800-1000$ & $1000-1200$ & More than 1200 \\
Issyk-Kul & $600-800$ & $800-600$ & $600-200$ & $400-200$ & 400 \\
Ak-Sai-Sary-Zhaz & - & - & - & $500-200$ & Below 200 \\
Inner Tenir-Too & $1000-800$ & $800-600$ & $600-400$ & $400-200$ & Below 200
\end{tabular}

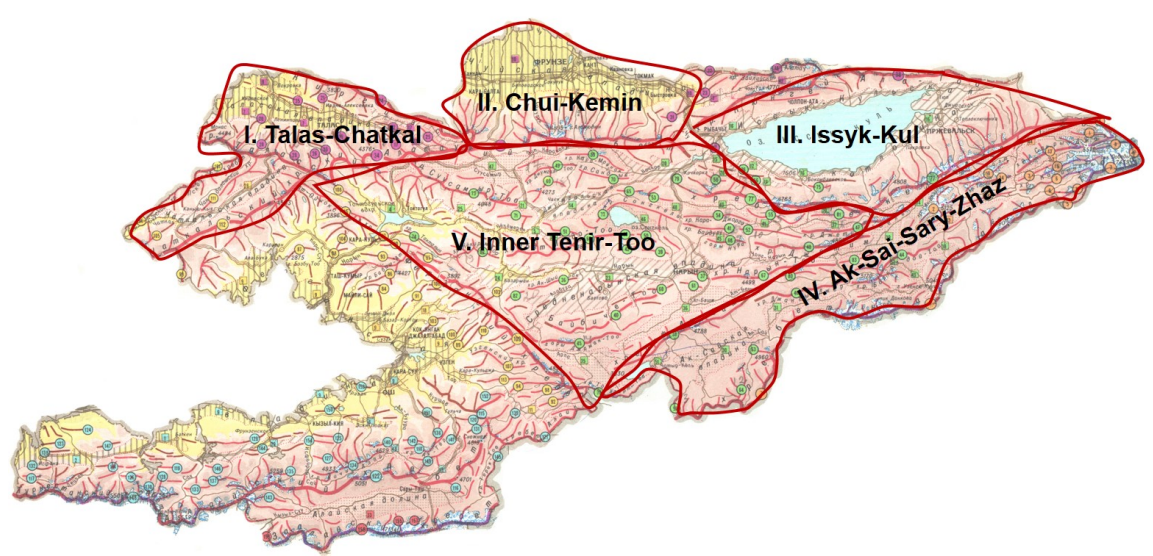

Figure 1. Division of Tenir-Too region into sectors.

\section{Conclusion}

Division of Tenir-Too region into sectors is associated with the complexity of the mountain landscape. The reason is geographical position of Tehir-Too, located in the center of large physical and geographical countries (Central Asian plain, Central Asian mountains, Pamir-Alai mountains, and Kazakhstan plain), influence of mixing of altitudinal belts, as a result of which "double zones" consisting of several sub-belts were formed. As a result of cold air wind currents from the north Pamir-Alai sector, and hot air currents from the Central Asia desert and the Kazakh steppes, analogical landscape of the neighboring regions was formed in the adjacent territories.

\section{Conflicts of Interest}

The authors declare no conflicts of interest regarding the publication of this paper.

\section{References}

Agakhanyants, A. E. (1981). Arid Mountains of the USSR (pp. 31-32). Moscow: Mysl.

Chediya, S. K. (1971). South of Central Asia in the Recent Era of Mountain Building (Vol. 1, pp. 71-73). Frunze: Ilim. 
Chlachula, J. (2019). Environmental Context and Adaptations of Prehistoric and Early Historical Occupation in the Southern Altai (SW Siberia-East Kazakhstan). Archaeological and Anthropological Sciences, 11, 2215-2236.

https://doi.org/10.1007/s12520-018-0664-0

Glazovskaya, M. A. (1955). Nature of the Tien Shan Syrts and Peculiarities of Soil Formation. In L. S. Berg (Ed.), Collection of Memories of the Academic (pp. 27-28). Moscow: Leningrad.

Lyubimtseva, E., \& Henebry, G. M. (2009). Climate and Environmental Change in Arid Central Asia: Impacts, Vulnerability, and Adaptations. Journal of Arid Environments, 73, 963-977. https://doi.org/10.1016/j.jaridenv.2009.04.022

Loskutov, V. V. (1969). About the Speed of the Newest Uplift of the Pamirs. In Neotectonics and Seismotectonics of Tajikistan (pp. 81-83). Dushanbe.

Mamytov, A. M. (1964). Soils of the Central Tien Shan (pp. 21-22). Frunze: Academy of Sciences.

Monier, E., Paltsev, S., Sokolov, A., Chen, Y.-H.H., Gao, X., Ejaz, Q., Couzo, E., Schlosser, C. A., Dutkiewicz, S., Scott, J., Fant, C., Kicklighter, D., Morris, J., Jacoby, H., Prinn, R., \& Haigh, M. (2018). Toward a Consistent Modeling Framework to Assess Multi-Sectoral Climate Impacts. Nature Communications, 9, 660.

https://doi.org/10.1038/s41467-018-02984-9

Pahamov, M. M. (1971). Some Questions of Studying the Mountains of Central Asia. In Palynology of the Holocene (153 p.). Moscow: Mysl.

Popova, A. I. (1967). Types of Vegetation in the Upper Reaches of the Naryn and Tarim. In The Flora of the Highlands of the USSR and Questions of Its Use (pp. 131-141). Frunze: Mysl.

Sherbaeva, Z. E. (2009). Dissertation Abstract (p. 29). Bishkek: Bilim.

Shrestha, D., Deshar, R., \& Nakamura, K. (2015). Characteristics of Summer Precipitation around the Western Ghats and the Myanmar West Coast. International Journal of Atmospheric Sciences, 2015, Article ID: 206016. https://doi.org/10.1155/2015/206016

Kalesnik, S. V. (1968). Encyclopedic Dictionary of Geographical Terms (337 p.). Moscow: Soviet Encyclopedia.

Vyhodtsev, I. V. (1967). Experience of Classification of Vegetation of the Tien Shan-Alai Mountain Structure. In Flora of the Highlands of the USSR and Issues of Its Use (pp. 14-24). Frunze: Mysl. 